\title{
An elevated respiratory quotient predicts complications after cardiac surgery under extracorporeal circulation: an observational pilot study
}

\author{
J. Piot ${ }^{1}$ (D) A. Hébrard ${ }^{1} \cdot$ M. Durand ${ }^{1} \cdot$ J. F. Payen ${ }^{1} \cdot$ P. Albaladejo $^{1}$
}

Received: 24 January 2018 / Accepted: 31 March 2018 / Published online: 17 April 2018

๑) Springer Science+Business Media B.V., part of Springer Nature 2018

\begin{abstract}
Following cardiac surgery, hyperlactatemia due to anaerobic metabolism is associated with an increase in both morbidity and mortality. We previously found that an elevated respiratory quotient (RQ) predicts anaerobic metabolism. In the present study we aimed to demonstrate that it is also associated with poor outcome following cardiac surgery. This single institution, prospective, observational study includes all those patients that were consecutively admitted to the intensive care unit (ICU) after cardiac surgery with cardiopulmonary bypass, that had also been monitored using pulmonary artery catheter. Data were recorded at admission ( $\mathrm{H} 0)$ and after one hour ( $\mathrm{H} 1)$ including: oxygen consumption $\left(\mathrm{VO}_{2}\right)$, carbon dioxide production $\left(\mathrm{VCO}_{2}\right), \mathrm{RQ}\left(\mathrm{VO}_{2} / \mathrm{VCO}_{2}\right)$, lactate levels and mixed venous oxygen saturation $\left(\mathrm{SvO}_{2}\right)$. The primary endpoint was defined as mortality at 30 days. Comparison of the area under the curve (AUC) for receiver operating characteristic curves was used to analyze the prognostic predictive value of $\mathrm{RQ}$, lactate levels and $\mathrm{SvO}_{2}$, in terms of patient outcome. We studied 151 patients admitted to the ICU between May 2015 and February 2016. Seventy eight patients experienced a worse than expected outcome in the post-operative period, and among those seven died. RQ at $\mathrm{H} 1$ in non-survivors $(0.83 \pm 0.08)$ was higher than in survivors $(0.75 \pm 0.09 ; \mathrm{p}=0.02)$. The AUC for RQ to predict mortality was $0.77\left(\mathrm{IC}_{95 \%}[0.70-0.84]\right)$, with a threshold value of 0.76 (sensitivity $64 \%$, specificity $100 \%$ ). By comparison, the AUC for lactate levels was significantly superior (AUClact 0.89, $\mathrm{IC}_{95 \%}$ [0.83-0.93], $\mathrm{p}=0.02$ ). In this study, elevated RQ appeared to be predictive of mortality after cardiac surgery with CPB.
\end{abstract}

Keywords Post-operative $\cdot$ Lactate $\cdot \mathrm{SvO}_{2} \cdot$ Mortality $\cdot$ Organ failure $\cdot$ Respiratory quotient

\section{Introduction}

The major cause of mortality and morbidity after cardiac surgery is the occurrence of low cardiac output syndrome (LCOS) due to myocardial dysfunction [1,2]. This can induce renal failure with a possible need of renal replacement therapy, hemodynamic failure with necessity for circulatory assistance or the administration of dobutamine, or neurological failure with confusion. Hyperlactatemia and low mixed venous oxygen saturation $\left(\mathrm{SvO}_{2}\right)$ are often used as indicators of anaerobic metabolism and tissue hypoxia due to LCOS after cardiac surgery [3, 4]. In their study of 325 patients who had undergone cardiac surgery, Maillet et al. [5] found an association between lactate levels above

$\triangle$ J. Piot

jpiot@chu-grenoble.fr

1 PAR CHU Grenoble Alpes, CS 10217, 30043 Grenoble Cedex 9, France
$3 \mathrm{mmol} / \mathrm{L}$ upon intensive care unit (ICU) admission, and higher risk of morbidity and mortality, thereby indicating hyperlactatemia as an important prognostic factor. Consistently, another study suggested that patients spend less time in the ICU and have a better post-surgical outcome when lactate levels are maintained under $2 \mathrm{mmol} / \mathrm{L}$ and/or $\mathrm{SvO}_{2}$ above $70 \%$ [6].

For all patients undergoing general anesthesia, the metabolic demand for oxygen gradually increases [7] during the post-operative period, due to several factors: emergence from anesthesia, pain, increase in body temperature and shivering, and recovery of spontaneous ventilation. Perioperative cardiopulmonary bypass (CPB) also causes an important neuroendocrine reaction [8] whereby organisms react firstly by increasing cardiac output (CO) and oxygen delivery $\left(\mathrm{DO}_{2}\right)$, and secondly by increasing oxygen extraction $\left(\mathrm{EO}_{2}\right)$ [9]. These necessary adaptive mechanisms may nevertheless be insufficient, and can result in a mismatch between oxygen demand and supply. In a more general 
context, studies have shown that morbidity was due to an increase in $\mathrm{EO}_{2}$ and low $\mathrm{SvO}_{2}$ at admission, rather than to conventional risk factors $[3,10]$. In contrast, other studies have questioned the reliability of $\mathrm{SvO}_{2}$ as an indicator of morbidity [11]. Additionally, it has been demonstrated that normal $\mathrm{SvO}_{2}$ can be falsely reassuring in cases of $\mathrm{EO}_{2}$ abnormalities (tissue hypoxia with normal $\mathrm{SvO}_{2}$ ) [12].

During hypoxia, anaerobic metabolism creates hydrogen ions and lactic acid. Hydrogen ions are buffered by bicarbonate, which increases tissue carbon dioxide levels. This phenomenon is undetected if $\mathrm{CO}$ is sufficient to eliminate carbon dioxide excess. Therefore, studying venous-arterial carbon dioxide difference $\left(\mathrm{Cv}-\mathrm{aCO}_{2}\right)$ alone cannot eliminate the possibility that anaerobic metabolism is taking place $[13,14]$.

In contrast, an increase in carbon dioxide production $\left(\mathrm{VCO}_{2}\right)$ and the ratio between this and the oxygen consumption $\left(\mathrm{VO}_{2}\right)$ (respiratory quotient [RQ]) are thought to be more significant parameters. During septic shock, Mekontso-Dessap et al. [15] found that the ratio between veno-arterial carbon dioxide tension difference $\left(\Delta \mathrm{PCO}_{2}\right)$ and arterial-venous oxygen difference $\left(\mathrm{Ca}-\mathrm{vO}_{2}\right)$ had the highest correlation with arterial lactate level. Moreover, in cardiac surgery, increases in $\mathrm{VCO}_{2}$ and RQ during extracorporeal circulation predict hyperlactatemia [16]. Interestingly, calculation of RQ is possible continuously, and without blood sampling during mechanical ventilation, by using indirect calorimetry to measure $\mathrm{VO}_{2}$ and $\mathrm{VCO}_{2}$ $\left(\mathrm{RQ}=\mathrm{VO}_{2} / \mathrm{VCO}_{2}\right)$.

The current study aims to evaluate the relationship between RQ and mortality after cardiac surgery. Secondary aims are to assess if a high RQ is associated with organ dysfunction, and to compare its performance at predicting prognosis to that of $\mathrm{SvO}_{2}$ and arterial lactate levels.

\section{Materials and methods}

\subsection{Study protocol}

The following protocol has been approved by the local ethics committee. This is a single institution, prospective and observational study conducted in a cardiothoracic ICU. Over a 10 month period, all patients consecutively admitted to the ICU after cardiac surgery with CPB, who had also been monitored using pulmonary artery catheters (Swan Ganz, CCOMBO V, Edwards Lifes Sciences, Irvine, CA, USA) were included in this study.

The decision to use a pulmonary artery catheter was made by the anesthesiologist according to our protocol: a Swan-Ganz catheter was usually used for patients with a low left ventricular ejection fraction $(L V E F<40 \%)$, pulmonary hypertension, recent myocardial infarction, or undergoing a redo or combined (valve plus bypass) surgery. Patients undergoing emergency surgery (aortic aneurysm, heart transplantation), receiving extracorporeal membrane oxygenation (ECMO) or under 18 years old were excluded from the study.

All patients were fitted with a radial artery catheter and a central venous catheter. During surgery, induction and maintenance of anesthesia was achieved via the continuous and target controlled infusion (TCI) of propofol and remifentanil provided by the Orchestra Base Primea (Fresenius Vial ${ }^{\circledR}$ ) infusion system. A neuromuscular blocking agent (cisatracurium) was used to facilitate tracheal intubation. Standard patient monitoring was performed during the surgery. Concerning CPB, every patient received the same priming fluid protocol: $700 \mathrm{~mL}$ of Isofundine $®$ and $500 \mathrm{~mL}$ of HES. The mean arterial pressure goal (between 60 and $80 \mathrm{mmHg}$ ) was maintained in every patient, with a pump flow of $2.2 \mathrm{~L} / \mathrm{min} / \mathrm{m}^{2}$. After surgery, a continuous infusion of propofol and remifentanil was maintained during transfer to the ICU.

In the ICU, patients were sedated with propofol (1-2 $\mathrm{mg} / \mathrm{kg} / \mathrm{h})$ and remifentanil $(0.05-0.10 \mu \mathrm{g} / \mathrm{kg} / \mathrm{min})$ and connected to an Engström-Carestation ventilator (General Electric HealthCare) with a CAiVOX® metabolic module. This module includes a fast response paramagnetic oxygen analyzer, an infrared carbon dioxide measurement tool and a pneumotachograph to measure inhaled and exhaled volumes. It thus allows for measurements of $\mathrm{VO}_{2}$ and $\mathrm{VCO}_{2}$ at each respiratory cycle, along with a RQ calculation via indirect calorimetry [17]. The measured respiratory gases were sampled via a connector near the Y-shaped section of the respiratory circuit. A controlled-volume ventilation mode was used with a tidal volume $(\mathrm{Vt})$ of between 6 and $8 \mathrm{~mL} / \mathrm{kg}$ of ideal body weight, a respiratory rate (RR) of 15 adapted to the results of the arterial gasometry for normocapnia, and a fraction of inspired oxygen $\left(\mathrm{FiO}_{2}\right)$ set at $40 \%$ then adjusted to preserve normoxia. Anesthesia was maintained until the patient was stable and normothermic, without excessive bleeding.

In view of the observational nature of the study, it was deemed unnecessary to calculate the number of subjects required. However, to ensure the correct description of abnormalities, 150 patients were considered as sufficient. Every patient included in the study verbally received information about the study and could decline to participate.

\subsection{Data collection}

The following data were recorded:

Demographic characteristics age, sex, weight, height, calculated body surface area, type of surgery, LVEF (\%) and 
the European system for cardiac operation risk evaluation (EuroSCORE II).

Hemodynamic parameters heart rate; systolic, diastolic and mean blood pressure; cardiac index; central venous pressure (CVP); systolic, diastolic and mean pulmonary artery pressure; pulmonary artery occlusion pressure (PAOP); systemic vascular resistance and pulmonary vascular resistance (SVR and PVR); support from inotropes and vasopressors, both qualitative and quantitative.

Ventilation parameters $\mathrm{Vt}, \mathrm{FiO}_{2}$ and end-tidal carbon dioxide $\left(\mathrm{EtCO}_{2}\right)$.

Metabolic parameters $\mathrm{VO}_{2}, \mathrm{VCO}_{2}$ and RQ.

Biological parameters arterial and mixed venous blood gases, arterial lactate, $\mathrm{SvO}_{2}$, hemoglobin and arterial and venous oxygen content $\left(\mathrm{CaO}_{2}\right.$ and $\left.\mathrm{CvO}_{2}\right)$ were all recorded using a RapidLab ${ }^{\circledR}$ series 1265 (Siemens HealthCare Diagnostics).

The following equations were used to calculate these parameters:

$$
\begin{aligned}
& \mathrm{CaO}_{2}=\left(1.34 \times \mathrm{SaO}_{2} \times \mathrm{Hb}\right)+\left(0.003 \times \mathrm{PaO}_{2}\right) \\
& \mathrm{CvO}_{2}=\left(1.34 \times \mathrm{SvO}_{2} \times \mathrm{Hb}\right)+\left(0.003 \times \mathrm{PvO}_{2}\right) \\
& \mathrm{Ca}-\mathrm{vO}_{2}=\mathrm{CaO}_{2}-\mathrm{CvO}_{2} \\
& \mathrm{EO}_{2}=\frac{\mathrm{Ca}-\mathrm{vO}_{2}}{\mathrm{CaO}_{2}} \\
& \mathrm{DO}_{2}=\mathrm{CaO}_{2} \times \mathrm{CO} \\
& \Delta \mathrm{PCO}_{2}=\mathrm{PvCO}_{2}-\mathrm{PaCO}_{2}
\end{aligned}
$$

whereby $\mathrm{Hb}$ refers to hemoglobin. $\mathrm{PaO}_{2}$ refers to the partial pressure of oxygen in arterial blood. $\mathrm{PvCO}_{2}$ refers to partial pressure of carbon dioxide in mixed venous blood. $\mathrm{Ca}$ refers to the oxygen concentration of arterial blood. $\triangle \mathrm{PCO}_{2}$ refers to veno-arterial carbon dioxide tension difference. $\mathrm{PaCO}_{2}$ refers to the partial pressure of carbon dioxide in arterial blood. All other abbreviations have previously been expanded upon in the text above.

Hemodynamic, ventilation, metabolic and biological data were collected one hour after admission of the patient in ICU (H1). Patient temperature remained stable during blood recordings $\left(36-37^{\circ} \mathrm{C}\right)$. In addition, biological data (renal and liver function, hemoglobin and electrolyte panels) were recorded at admission (day 1), and again the day after admission (day 2), in order to calculate the sequential organ failure assessment (SOFA) score.

The patients were monitored for 30 days post-surgery; at this time, patient outcome was recorded (whether the patient had died, or was currently residing in hospital, at home or in a rehabilitation center). All data were anonymized and recorded in the database. The person responsible for collecting the data was not in charge of the patient care. Patients with missing data concerning RQ, respiratory gases, lactate level or $\mathrm{SvO}_{2}$ were not included in the statistical analysis.

The primary endpoint of this study was defined as mortality at 30 days. Secondary endpoints included: the occurrence of a LCOS at day 2 (renal failure corresponding to a KDIGO classification of stage 2 or higher, with renal replacement therapy or an increase in serum creatinine to more than two times the basal value, and/or hemodynamic failure with necessity for circulatory assistance or the administration of dobutamine at more than $3 \mu \mathrm{g} / \mathrm{kg} / \mathrm{min}$ for more than $12 \mathrm{~h}$ ), a post operative ICU length of stay of more than $72 \mathrm{~h}$, or a hospital length of stay of more than 14 days.

\subsection{Statistical analysis}

Data were analyzed using t tests for continuous variables and chi-2 analysis for categorical variables. The prognosispredictive performances of RQ, lactate levels and $\mathrm{SvO}_{2}$ were assessed using area under the curve (AUC) measurements for receiver operating characteristic (ROC) curves. The Youden index was used to select the optimal threshold value. Data are expressed as median, minimum and maximum. A p-value of less than 0.05 was considered statistically significant.

Statistical analyses were performed using

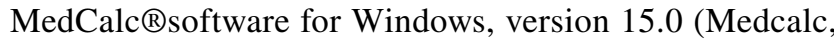
Ostend, Belgium).

\section{Results}

\subsection{Population}

Between May 20th 2015 and February 19th 2016, we consecutively included 162 patients admitted to the ICU after cardiac surgery. Eleven patients were excluded due to missing data (three for failure to record RQ, and eight due to missing gas analysis data). A flowchart depicting the patient population is shown in Figure 1.

Patients characteristics are outlined in Table 1.

In our population, seven patients died while in the ICU. Concerning complications, 45 patients developed a LCOS, and 71 patients had a higher than expected length of stay (more than $72 \mathrm{~h}$ in ICU, or more than 14 days in hospital). All the results concerning RQ described in next section can be found in Table 2.

\subsection{Primary endpoint}

\subsubsection{Univariate analysis}

RQ at $\mathrm{H} 1$ was significantly higher in non-survivors than in survivors ( $0.83 \pm 0.08$ vs. $0.75 \pm 0.08 ; p=0.02)$ (see Fig. 2). 


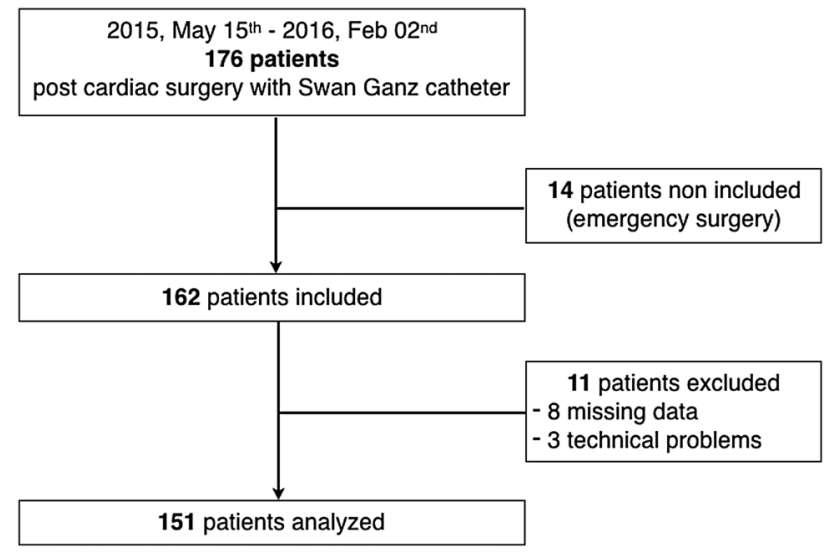

Fig. 1 Flow chart

Lactate levels were found to be significantly higher in non-survivors than survivors $(2.7 \pm 0.5$ vs. $1.4 \pm 0.6$; $p<0.001) . \mathrm{SvO}_{2}$ levels were significantly lower in nonsurvivors than in survivors $(57.3 \pm 12.4$ vs. $64.6 \pm 7.6 ; \mathrm{p}=$ 0.02) (see Fig. 3a, b).

\subsubsection{ROC curves}

Concerning mortality, the AUC for RQ was 0.77 ( $\mathrm{IC}_{95 \%}$ [0.69-0.84]) and for lactate levels it was $0.89\left(\mathrm{IC}_{95 \%}\right.$ [0.83-0.93]). The predictive value of lactate levels was significantly higher than that of $R Q(p=0.02)$. No difference in the AUC was found between RQ and $\mathrm{SvO}_{2}\left(\mathrm{AUC} 0.71\left(\mathrm{IC}_{95 \%}\right.\right.$ [0.63-0.78]); $p=0.62$ ). These results are shown in Figure 4.

The optimal threshold value for RQ is 0.76 , with $100 \%$ sensitivity and $64 \%$ specificity.

\subsection{Secondary endpoints}

\subsubsection{LCOS}

Forty patients presented with LCOS, five whom with renal failure, a further four benefited from renal replacement therapy, 34 presented with hemodynamic failure and need of dobutamine.

Patients with LCOS tended to have a higher RQ $(0.78 \pm 0.08)$ than other patients $(0.75 \pm 0.08)$, however this difference did not reach statistical significance $(\mathrm{p}=0.08)$.

There was also no statistical difference between AUCs for $\mathrm{RQ}$, lactate and $\mathrm{SvO}_{2}$ concerning patient outcome, as shown in Table 3.

\subsubsection{Length of stay (LOS)}

Seventy-six patients had a higher than expected length of stay: 56 patients stayed more than 3 days in the ICU and 46 patients stayed more than 14 days in hospital. Patients with a higher length of stay did tend to have a higher RQ $(0.77 \pm 0.08)$ than other patients $(0.75 \pm 0.09)$, however this difference did not reach statistical significance $(\mathrm{p}=0.056)$ (see Fig. 5).

Moreover, there was no significant difference between the AUCs for RQ, lactate levels and $\mathrm{SvO}_{2}$ concerning length of stay, as shown in Table 4.

\section{Discussion}

\subsection{Anaerobic metabolism and RQ}

The main finding of this study is that after cardiac surgery, an elevated RQ 1 hour after arrival in the ICU was significantly associated with mortality.

$\mathrm{RQ}$ elevation during anaerobic metabolism is linked to an increase in $\mathrm{VCO}_{2}[15,18]$. RQ is used to determine the anaerobic threshold in sport training [19]. During normoxia, $\mathrm{VCO}_{2}$ is correlated with $\mathrm{VO}_{2}$. When a mismatch between oxygen demand and supply occurs, tissue hypoxia can be observed, with cells producing lactate and hydrogen ions via the anaerobic pathway, in turn increasing $\mathrm{VCO}_{2}$.

Other studies have found a relationship between RQ and mortality in critically ill patients. Ranucci [16] studied the predictive value of carbon dioxide-derived parameters during cardiac surgery. They found that an increase in $\mathrm{VCO}_{2}$ and RQ during CPB (threshold value 0.9) was correlated with hyperlactatemia. In our study, we observed a similar correlation between RQ and mortality, with a threshold value of 0.76 .

In another context Monnet et al. [20] compared $\mathrm{SvO}_{2}$ and anaerobic markers (lactate levels and the ratio between veno-arterial carbon dioxide tension difference $\left[\Delta \mathrm{PCO}_{2}\right]$ and arterio-venous oxygen content difference $\left[\mathrm{Ca}-\mathrm{vO}_{2}\right]$ ) in septic patients as a substitute for RQ. Patients with an increased $\mathrm{VO}_{2}$ after fluid expansion were characterized by a higher lactate level and a higher $\Delta \mathrm{PCO}_{2} / \mathrm{Ca}-\mathrm{vO}_{2}$ ratio, compared to those showing no increase in $\mathrm{VO}_{2}$. $\mathrm{SvO}_{2}$ did not predict this increase in $\mathrm{VO}_{2}$. They concluded that anaerobic markers should be used instead of $\mathrm{SvO}_{2}$ as indicators to initiate hemodynamic resuscitation in septic patients. Although interesting, these results need to be validated in a surgical context. Assuming the Fick equation, $\mathrm{VCO}_{2}$ and $\mathrm{VO}_{2}$ are respectively linearly correlated to $\mathrm{Cv}-\mathrm{aCO}_{2}$ and $\mathrm{Ca}-\mathrm{vO}_{2}$. In consideration of the Haldane effect and relationship between central venous carbon dioxide concentration $\left(\mathrm{CvCO}_{2}\right), \mathrm{SvO}_{2}$ and $\mathrm{PCO}_{2}$, the ratio between $\Delta \mathrm{PCO}_{2}$ and $\mathrm{Ca}-\mathrm{vO}_{2}$ appears therefore to be correlated with $\mathrm{RQ}$. Both ratios $\left(\Delta \mathrm{PCO}_{2} / \mathrm{Ca}-\mathrm{vO}_{2}\right.$ and $\left.\mathrm{RQ}\right)$ can predict tissue hypoxia, allowing for the initiation of early hemodynamic resuscitation. 
Table 1 Population characteristics

\begin{tabular}{|c|c|c|c|c|c|c|c|}
\hline $\begin{array}{l}\text { Characteristics } \\
\text { (med; [min- } \\
\max ])\end{array}$ & $\mathrm{N}(\mathrm{n}=151)$ & $\begin{array}{l}\text { Non survivors } \\
(\mathrm{n}=7)\end{array}$ & $\begin{array}{l}\text { Survivors }(\mathrm{n}= \\
144)\end{array}$ & $\operatorname{LCOS}(n=40)$ & $\begin{array}{l}\text { No } \operatorname{LCOS}(\mathrm{n}= \\
111)\end{array}$ & $\begin{array}{l}\text { Length of stay } \\
\text { higher }(n=76)\end{array}$ & $\begin{array}{l}\text { Length of stay } \\
\text { usual }(n=75)\end{array}$ \\
\hline Age (years) & $72[30-88]$ & $73[63-83]$ & $71[30-88]$ & $70[35-88]$ & $72[30-85]$ & $74[35-88]$ & $68[30-85]$ \\
\hline \multicolumn{8}{|l|}{$\operatorname{Sex}(n)$} \\
\hline Male & 106 & 6 & 100 & 25 & 81 & 44 & 62 \\
\hline Euroscore $(\%)$ & $2.8[0.5-15.9]$ & $9.8[2-15.9]$ & $2.8[0.5-15]$ & $3.9[0.7-14.9]$ & $2.5[0.5-15.9]$ & $4.0[0.7-15.0]$ & $2.2[0.5-15.9]$ \\
\hline \multicolumn{8}{|l|}{ Surgery(n) } \\
\hline Valve & 93 & 2 & 91 & 25 & 68 & 49 & 44 \\
\hline Bypass & 24 & 0 & 24 & 6 & 18 & 6 & 18 \\
\hline $\begin{array}{l}\text { Combined } \\
\text { surgery }\end{array}$ & 27 & 3 & 24 & 7 & 20 & 16 & 11 \\
\hline Other & 7 & 2 & 5 & 2 & 5 & 5 & 2 \\
\hline \multicolumn{8}{|c|}{ Pre-op. characteristics } \\
\hline $\operatorname{LVEF}(\%)$ & $65[25-80]$ & $65[35-80]$ & $60[25-80]$ & $59[25-80]$ & $61[30-80]$ & $63[25-80]$ & $60[30-80]$ \\
\hline $\begin{array}{l}\text { Pre op. renal } \\
\text { failure (n) }\end{array}$ & 123 & 7 & 116 & 35 & 88 & 63 & 60 \\
\hline \multicolumn{8}{|c|}{ Surgery duration (min) } \\
\hline СРB & $115[45-300]$ & 162 [59-262] & 116 [45-300] & 128 [59-262] & $113[45-300]$ & 117 [48-262] & $117[45-300]$ \\
\hline $\begin{array}{l}\text { Aortic clamp- } \\
\text { ing }\end{array}$ & $84[0-205]$ & 86 [34-158] & $84[0-205]$ & 87 [34-149] & $82[0-205]$ & $86[28-158]$ & $82[0-205]$ \\
\hline Total & $300[80-630]$ & $320[240-630]$ & $300[80-560]$ & $335[180-630]$ & $300[80-600]$ & $300[180-630]$ & $300[80-360]$ \\
\hline \multicolumn{8}{|c|}{ Per-op vasopressors (mg) } \\
\hline Dobutamine & $0.0[0.0-94.0]$ & $34.2[0.0-94.0]$ & $0.0[0.0-67.7]$ & $8.9[0.0-94.0]$ & $0.0[0-67.7]$ & $0.0[0.0-94.0]$ & $0.0[0.0-47.9]$ \\
\hline Noradrenaline & $0.4[0.0-11.0]$ & $3.8[1.4-7.8]$ & $0.4[0.0-11.0]$ & $0.8[0.0-11.0]$ & $0.3[0.0-7.8]$ & $0.5[0.0-7.8]$ & $0.2[0.0-11.0]$ \\
\hline \multicolumn{8}{|l|}{ Hemodynamic } \\
\hline $\begin{array}{l}\text { MAP H1 } \\
(\mathrm{mmHg})\end{array}$ & $71[44-120]$ & $72[59-75]$ & $71[33-120]$ & $71[44-96]$ & $71[33-120]$ & $69[44-102]$ & $73[33-120]$ \\
\hline $\begin{array}{l}\text { CVP H1 } \\
\quad(\mathrm{mmHg})\end{array}$ & $9[1-19]$ & 8 [6-19] & 9 [1-19] & 8 [3-19] & 9 [1-19] & $9[3-19]$ & $9[1-18]$ \\
\hline $\begin{array}{c}\mathrm{CI} \mathrm{H} 1(\mathrm{~mL} / \\
\left.\mathrm{min} / \mathrm{m}^{2}\right)\end{array}$ & $1.8[0.9-3.6]$ & $1.5[1.3-2.4]$ & $1.8[0.9-3.6]$ & $1.6[1.1-3.3]$ & $1.9[0.9-3.6]$ & $1.8[0.9-3.3]$ & $1.9[1.0-3.6]$ \\
\hline \multicolumn{8}{|c|}{ Biological characteristics } \\
\hline pH H1 & $7.32[7.19-7.48]$ & $7.35[7.20-7.38]$ & $\begin{array}{l}7.32[7.19- \\
7.48]\end{array}$ & $\begin{array}{l}7.33[7.22- \\
7.45]\end{array}$ & $\begin{array}{l}7.31[7.19- \\
7.48]\end{array}$ & $\begin{array}{l}7.32[7.19- \\
7.45]\end{array}$ & $7.33[7.19-7.48]$ \\
\hline $\begin{array}{l}\text { Lactate H1 } \\
\quad(\mathrm{mmoL} / \mathrm{L})\end{array}$ & $1.3[0.5-6.0]$ & $2.0[1.7-6.0]$ & $1.2[0.5-4.4]$ & $1.3[0.9-3.7]$ & $1.2[0.5-6.0]$ & $1.3[0.8-6.0]$ & $1.2[0.5-4.4]$ \\
\hline $\mathrm{SvO}_{2} \mathrm{H} 1(\%)$ & 66 [43-93] & 58 [43-77] & 66 [44-93] & $63[43-74]$ & 66 [44-93] & 64 [43-77] & 67 [49-93] \\
\hline RQ H1 & $0.75[0.60-1.01]$ & $0.79[0.77-1.01]$ & $\begin{array}{l}0.75[0.60- \\
1.00]\end{array}$ & $\begin{array}{l}0.77[0.60- \\
1.01]\end{array}$ & $\begin{array}{l}0.75[0.62- \\
1.00]\end{array}$ & $\begin{array}{l}0.76[0.62- \\
1.01]\end{array}$ & $0.74[0.60-0.95]$ \\
\hline SOFA score & 7 [2-16] & 12 [8-16] & 7 [2-14] & 9 [2-16] & 7 [2-16] & 8 [2-16] & 7 [2-14] \\
\hline $\begin{array}{l}\text { ICU duration } \\
\text { (days) }\end{array}$ & 3 [1-25] & $6[2-25]$ & $3[1-15]$ & $4[1-25]$ & $3[1-14]$ & $4[1-25]$ & $2[1-3]$ \\
\hline
\end{tabular}

$L V E F$ left ventricular ejection fraction

$C P B$ cardio pulmonary bypass

$M A P$ mean arterial pressure

CVP central venous pressure

$C I$ Cardiac Index

$R Q$ respiratory quotient

Renal failure Cockroft creatinine clearance $<90 \mathrm{~mL} / \mathrm{min}$ 
Table 2 Primary and secondary outcome about RQ

\begin{tabular}{|c|c|c|c|c|c|c|}
\hline & $\begin{array}{l}\text { Non-survivors ( } \\
=7 \text { ) }\end{array}$ & Survivors $(n=144)$ & $\operatorname{LCOS}(n=40)$ & $\begin{array}{l}\text { Non LCOS }(\mathrm{n}= \\
111)\end{array}$ & $\begin{array}{l}\text { LOS higher }(\mathrm{n}= \\
76)\end{array}$ & LOS usual $(\mathrm{n}=75)$ \\
\hline RQ H1 & $0.83 \pm 0.08^{*}$ & $0.75 \pm 0.08$ & $0.78 \pm 0.09$ & $0.75 \pm 0.07$ & $0.77 \pm 0.08$ & $0.74 \pm 0.07 *$ \\
\hline Lactates levels H1 & $2.7 \pm 0.5^{*}$ & $1.4 \pm 0.6$ & $1.57 \pm 0.65$ & $1.42 \pm 0.73$ & $1.55 \pm 0.81$ & $1.35 \pm 0.58$ \\
\hline $\mathrm{SvO}_{2} \mathrm{H} 1$ & $57.3 \pm 12.4^{*}$ & $64.4 \pm 7.6$ & $62.0 \pm 8.6$ & $65.3 \pm 7.6 *$ & $63.1 \pm 8.2$ & $65.8 \pm 7.6 *$ \\
\hline
\end{tabular}

$*$ p-value $<0.05$

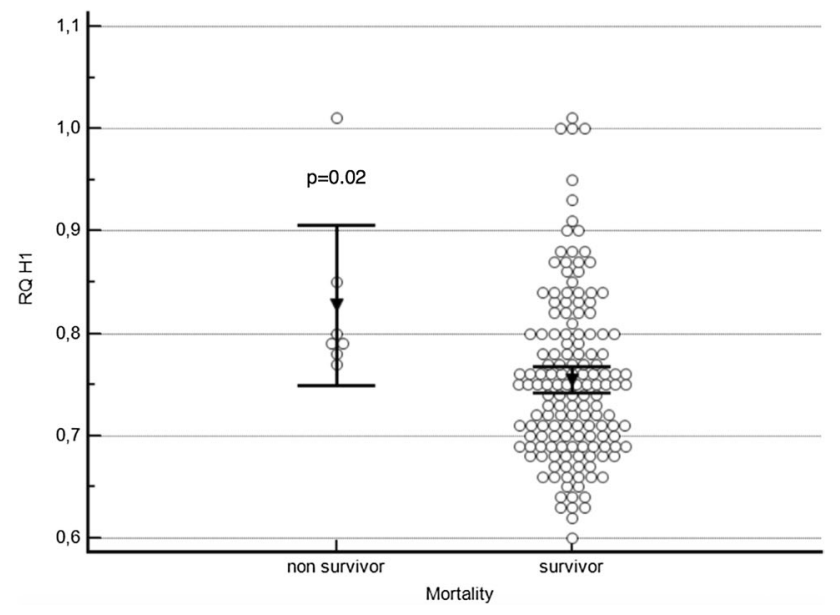

Fig. 2 RQ data on survival and non survival patients at $\mathrm{H} 1$

\subsection{Study of lactate and $\mathrm{SvO}_{2}$}

Increased lactate level is a well known factor associated with mortality after cardiac surgery. Smith et al. [21] found that lactate levels predict mortality in the ICU, with an AUC of 0.78 , as opposed to 0.89 ( $\left.\mathrm{IC}_{95 \%}[0.83-0.93]\right)$ in our study. The same findings are reported in several previous studies [22] regardless of liver function and lactate clearance [23].

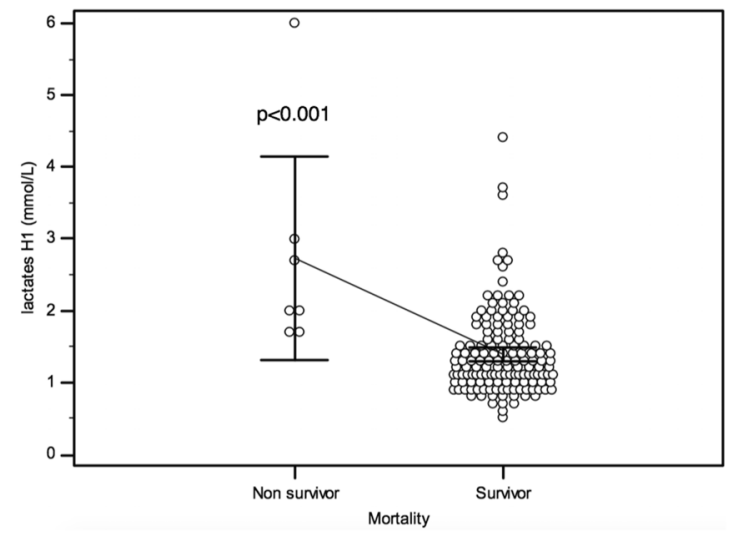

(a) Lactate data and mortality at $\mathrm{H} 1$
The occurrence of tissue hypoperfusion after cardiac surgery has been assessed using $\mathrm{SvO}_{2}$ and lactate criteria $(<70 \%$ and $>2 \mathrm{mmol} / \mathrm{L}$ respectively) [24]: patients who presented a $\mathrm{ScvO}_{2}<70 \%$ and lactate $>4 \mathrm{mmol} / \mathrm{L}$ (defining a severe tissue hypoperfusion), had significantly prolonged ICU stays. The authors noticed that at ICU admission, 32\% of these patients showed no clinical signs of shock (mean blood pressure of $>65 \mathrm{mmHg}$ and a urine output of $>0.5 \mathrm{~mL} / \mathrm{kg} / \mathrm{h}$ ). Therefore, measurement of $\mathrm{SvO}_{2}$ and lactate levels after cardiac surgery may help to identify occult hypoperfusion and guide hemodynamic optimization, before the onset of adverse clinical effects.

However, these criteria have several limitations. First, blood lactate levels are detected by discontinuous monitoring. Although serial tests are possible, they may be insufficient to allow for early and efficient hemodynamic optimization. Hyperlactatemia is an early marker for tissue hypoxia [25], but after prolonged anaerobic metabolism cellular and mitochondrial function are too impaired to be reverted to a normoxic state, despite hypoxia correction. The inability of cells to revert to a normoxic state after prolonged anaerobic metabolism may explain the results obtained by Gattinoni et al. [26]: this study showed no difference in mortality and morbidity between critically ill patients, even after $\mathrm{CO}$ or $\mathrm{SvO}_{2}$ correction. Secondly, lactate late onset hyperlactatemia is not always associated with an impairment of

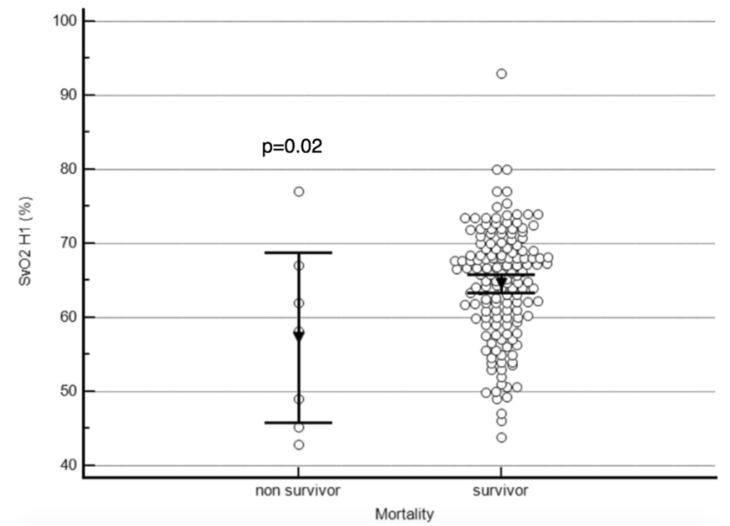

(b) $\mathrm{SvO}_{2}$ data and mortality at $\mathrm{H} 1$

Fig. 3 Lactate and $\mathrm{SvO}_{2}$ data for mortality at $\mathrm{H} 1$ 


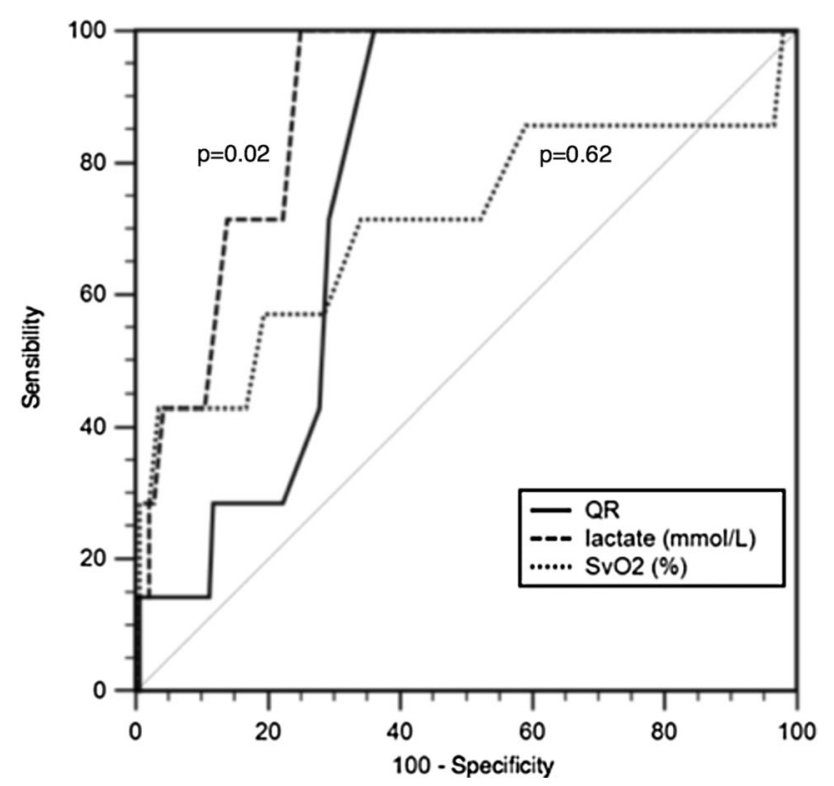

Fig. 4 ROC curves for mortality at H1

Table 3 AUC ROC curves for LCOS

\begin{tabular}{lll}
\hline Variable & AUC $\left[\mathrm{IC}_{95 \%}\right]$ & p-value \\
\hline $\mathrm{RQ}$ & $0.70[0.62-0.77]$ & \\
Lactate & $0.70[0.62-0.77]$ & 0.95 \\
$\mathrm{SvO}_{2}$ & $0.63[0.55-0.71]$ & 0.40 \\
\hline
\end{tabular}

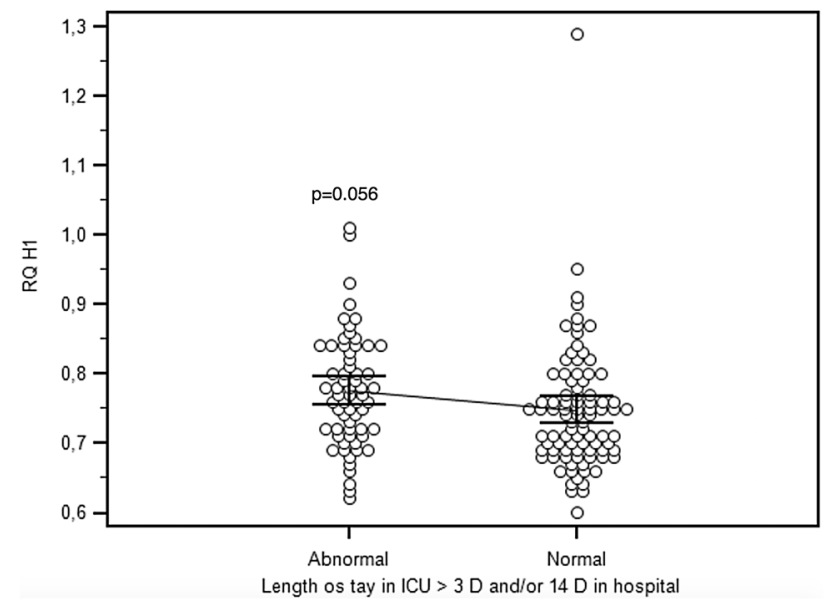

Fig. 5 RQ data and length of stay at H1

tissue perfusion or $\mathrm{O}_{2}$ delivery: two studies had reported an hyperlactatemia despite an adequate $\mathrm{CO}$ and oxygen delivery [27, 28]. Tissue microdialysis in patients with late onset hyperlactatemia found a rise in tissue lactate associated with a normal lactate/pyruvate ratio. Then origin of late onset
Table 4 AUC ROC curves for length of stay in $I C U>3 D$ and/or hospital $>14 D$

\begin{tabular}{llc}
\hline Variable & AUC $\left[\mathrm{IC}_{95 \%}\right]$ & p-value \\
\hline RQ & $0.63[0.54-0.70]$ & \\
Lactate & $0.59[0.51-0.67]$ & 0.55 \\
$\mathrm{SvO}_{2}$ & $0.58[0.50-0.66]$ & 0.49 \\
\hline
\end{tabular}

hyperlactatemia is unclear and is associated only with a slight increased mortality [5].

$\mathrm{SvO}_{2}$ is another useful tool used to monitor tissue oxygenation, but it is important to remember its determinants [29]: its value depends on hemoglobin, CO, oxygen saturation $\left(\mathrm{SaO}_{2}\right)$ and oxygen consumption, but also on dissolved oxygen. This final criterion is often overlooked because in the blood most oxygen is bound to hemoglobin. In critically ill patients, an increase in $\mathrm{SvO}_{2}$ is reported after increasing $\mathrm{FiO}_{2}$ [30], due to the elevation of dissolved oxygen. Therefore, before interpreting $\mathrm{a} \mathrm{SvO}_{2}$ value, it is firstly important to observe $\mathrm{FiO}_{2}$. In our study, patients were ventilated with $\mathrm{FiO}_{2}$ of $40-50 \%$ to achieve normoxia and this was unchanged during $\mathrm{SvO}_{2}$ investigation. $\mathrm{SvO}_{2}$ reflects the global balance between oxygen supply and demand in the entire organism, but it has been shown to be falsely reassuring in cases of regional tissue hypoxia [31,32]. Finally, monitoring of $\mathrm{SvO}_{2}$ requires the use of a pulmonary artery catheter, and the safety of these remain to be determined [33, 34].

\subsection{Limitations}

Our study presents several biases. Firstly, caregivers were not blinded to RQ values. Although RQ was not used during patient management as it is not included in our decision algorithms, it appeared on the ventilator screens. Therefore, its value may have influenced the decisions made by physicians regarding patient care. Moreover, we did not collect fluid management and bleeding during CPB as well as during post-operative period. We are aware it is a limitation in our study, as these factors can have an important effect on RQ. We should also have provided a full clinical overview by including confusion in our definition of LCOS during the post-operative period. These limitations may narrow the focus on RQ in our study.

Secondly, the mortality rate is around $4.6 \%$ in our population with a mean EuroSCORE 2 of $3.7 \pm 3.0$. This is higher than the mortality rate in other post-cardiac surgery population: in the original EuroSCORE2 study [35], mortality was $4.2 \%$ with a mean Euroscore at 3.9. This can possibly be explained by the relatively small number of patients and the wide $95 \%$ confidence interval of the death rate [1.8-9.6].

Finally, we conducted a single institution study, hence we cannot exclude a site specific effect concerning the 
management of cardiac patients in our hospital. Moreover, the selected population is not totally representative of all the post cardiac surgery patients.

\section{Conclusion}

In this first study, we found that an elevated RQ was correlated with mortality and morbidity due to LCOS after cardiac surgery, with a threshold value of 0.76 to predict mortality. We found a similar correlation with elevated lactate levels and, to a lesser extent, for reduced $\mathrm{SvO}_{2}$. These results suggest that RQ may have a role in the multimodal management of ICU patients. Further studies are required, particularly to help define a reliable threshold for RQ.

\section{Compliance with ethical standards}

Conflicts of interest The authors declare that they have no conflict of interest.

\section{References}

1. Giezeman A, Bosman RJ, Oudemans-van Straaten HM, der Spoel HI, Wester JPJ, Zandstra DF. Poster Sessions 598-724. Intensive Care Med. 2002;28(S1):S155-86. https://doi.org/10.1007/s0013 4-002-1458-4 ISSN 0342-4642.

2. Håkanson E, Svedjeholm R, Vanhanen I. Physiologic aspects in postoperative cardiac patients. Ann. Thorac. Surg. 1995;59(2 Suppl):S1214 ISSN 0003-4975.

3. Holm J, Håkanson E, Vánky F, Svedjeholm R. Mixed venous oxygen saturation predicts short- and long-term outcome after coronary artery bypass grafting surgery: a retrospective cohort analysis. Br. J. Anaesth. 2011;107(3):344-3450.

4. Holm J, Håkanson RE, Vánky F, Svedjeholm R. Mixed venous oxygen saturation is a prognostic marker after surgery for aortic stenosis. Acta Anaesthesiol. Scand. 2010;54(5):589-95. https:// doi.org/10.1111/j.1399-6576.2009.02205.x ISSN 00015172

5. Maillet JM, Le Besnerais P, Cantoni M, Nataf P, Ruffenach A, Lessana A, Brodaty D. Frequency, risk factors, and outcome of hyperlactatemia after cardiac surgery. Chest. 2003;123(5):1361-6. https://doi.org/10.1378/chest.123.5.1361 ISSN 00123692.

6. Pekka P, Esko R, Mikko H, Mikko P, Jukka T. A prospective, randomized study of goal-oriented hemodynamic therapy in cardiac surgical patients. Anesth. Analg. 2000;90(5):1052-9. https://doi. org/10.1097/00000539-200005000-00010 ISSN 0003-2999.

7. Chiara O, Giomarelli PP, Biagioli B, Rosi R, Gattinoni L. Hypermetabolic response after hypothermic cardiopulmonary bypass. Crit. Care Med. 1987;15(11):995-1000.

8. Pezzella T, Ferraris VA, Lancey RA. Care of the adult cardiac surgery patient: part I. Curr. Probl. Surg. 2004;41(5):458-516. https://doi.org/10.1016/j.cpsurg.2004.03.001 ISSN 00113840.

9. Kirkeby-Garstad I, Sellevold OFM, Stenseth R, Skogvoll E. Mixed venous oxygen desaturation during early mobilization after coronary artery bypass surgery. Acta Anaesthesiol. Scand. 2005;49(6):827-34. https://doi.org/10.111 1/j.1399-6576.2004.00617.x ISSN 0001-5172.

10. Pölönen P, Hippeläinen M, Takala R, Ruokonen E, Takala J. Relationship between intra- and postoperative oxygen transport and prolonged intensive care after cardiac surgery: a prospective study. Acta Anaesthesiol. Scand. 1997;41(7):810-7. https://doi. org/10.1111/j.1399-6576.1997.tb04793.x ISSN 00015172.

11. Futier E, Robin E, Jabaudon M, Guerin R, Petit A, Bazin J-E, Constantin J-M, Vallet B. Central venous $\mathrm{O}_{2}$ saturation and venous-to-arterial $\mathrm{CO}_{2}$ difference as complementary tools for goal-directed therapy during high-risk surgery. Crit. Care. 2010;14(5):R193. ISSN 1364-8535.

12. O'Connor JP, Townsend GE. Perioperative continuous monitoring of mixed venous oxygen saturation should be routine during high-risk cardiac surgery. J. Cardiothorac. Anesth. 1990;4(5):647-50. https://doi.org/10.1016/0888-6296(90)90416 -D ISSN 08886296.

13. Lamia B, Monnet X, Teboul JL. Meaning of arterio-venous PCO 2 difference in circulatory shock. Minerva Anestesiol. 2006;72(6):597-604 ISSN 0375-9393.

14. Vallet B, Teboul JL, Cain S, Curtis S. Venoarterial CO(2) difference during regional ischemic or hypoxic hypoxia. J. Appl. Physiol. 2000;89(4):1317-21. https://doi.org/10.1152/jappl .2000.89.4.1317 ISSN 8750-7587.

15. Mekontso-Dessap A, Castelain V, Anguel N, Bahloul M, Schauvliege F, Richard C, Teboul J-L. Combination of venoarterial $\mathrm{PCO}_{2}$ difference with arteriovenous $\mathrm{O}_{2}$ content difference to detect anaerobic metabolism in patients. Intensive Care Med. 2002;28(3):272-7. https://doi.org/10.1007/s00134-002-1215-8 ISSN 0342-4642.

16. Ranucci $M$. Which cardiac surgical patients can benefit from placement of a pulmonary artery catheter? Crit. Care. 2006;10(Suppl. 3):S6. https://doi.org/10.1186/cc4833 ISSN 13648535.

17. Brandi LS, Bertolini R, Calafà M. Indirect calorimetry in critically ill patients: clinical applications and practical advice. Nutrition. 1997;13(4):349-58 ISSN 0899-9007.

18. Faisy C, Taylor SJ. Dépense énergétique en réanimation. Reanimation. 2009;485(6):18-477. https://doi.org/10.1016/j.reaur g.2009.05.017 ISSN 16240693.

19. Geir S, Bjørn R, Skjønsberg OH, Borchsenius F. Respiratory gas exchange indices for estimating the anaerobic threshold. J. Sports Sci. Med. 2005;4(1):29-36 ISSN 1303-2968.

20. Monnet X, Julien F, Ait-Hamou N, Lequoy M, Gosset C, Jozwiak M, Persichini R, Anguel N, Richard C, Teboul JL. Lactate and venoarterial carbon dioxide difference/arterial-venous oxygen difference ratio, but not central venous oxygen saturation, predict increase in oxygen consumption in fluid responders. Crit. Care Med. 2013;41(6):1412-20. https://doi.org/10.1097/CCM.0b013 e318275cece ISSN 00903493.

21. Smith I, Kumar P, Molloy S, Rhodes A, Newman PJ, Grounds $\mathrm{RM}$, Bennett ED. Base excess and lactate as prognostic indicators for patients admitted to intensive care. Intensive Care Med. 2001;27(1):74-83. https://doi.org/10.1007/s001340051352 ISSN 03424642 .

22. Cecconi M, De Backer D, Antonelli M, Beale R, Bakker J, Hofer C, Jaeschke R, Mebazaa A, Pinsky MR, Teboul JL, Vincent JL, Rhodes A. Consensus on circulatory shock and hemodynamic monitoring: task force of the European Society of Intensive Care Medicine. Intensive Care Med. 2014;40(12):1795-815. https:// doi.org/10.1007/s00134-014-3525-z.

23. Kruse JA, Zaidi Syed AJ, Carlson RW. Significance of blood lactate levels in critically III patients with liver disease. Am. J. Med. 1987;83(1):77-82. https://doi.org/10.1016/0002-9343(87)90500 -6 ISSN 00029343.

24. Hu BBY, Laine GA, Wang S, Solis RT. Combined central venous oxygen saturation and lactate as markers of occult hypoperfusion and outcome following cardiac surgery. J. Cardiothorac. Vasc. Anesth. 2012;26(1):52-7. https://doi.org/10.1053/j. jvca.2011.07.021 ISSN 10530770. 
25. Valenza F, Aletti G, Fossali T, Chevallard G, Sacconi F, Irace M, Gattinoni L. Lactate as a marker of energy failure in critically ill patients: hypothesis. Crit. Care. 2005;9(6):588-93. https://doi. org/10.1186/cc3818 ISSN 13648535.

26. Gattinoni L, Brazzi L, Pelosi P, Latini R, Tognoni G, Pesenti A, Fumagalli R. A trial of goal-oriented hemodynamic therapy in critically Ill patients. N. Engl. J. Med. 1995;333(16):102532. https://doi.org/10.1056/NEJM199510193331601 ISSN 0028-4793.

27. Totaro RJ, Raper RF. Epinephrine-induced lactic acidosis following cardiopulmonary bypass. Crit. Care Med. 1997;25(10):1693-9.

28. Hosein RBM, Morris KP, Brawn WJ, Barron DJ. Use of tissue microdialysis to investigate hyperlactataemia following paediatric cardiac surgery. Interact. Cardiovasc. Thorac. Surg. 2008;7(3):384-8. https://doi.org/10.1510/icvts.2007.166264 ISSN 1569-9293.

29. Shepherd Stephen J, Pearse Rupert M. Role of central and mixed venous oxygen saturation measurement in perioperative care. Anesthesiology. 2009;111(3):649-56. https://doi.org/10.1097/ ALN.0b013e3181af59aa ISSN 15281175.

30. Legrand M, Mateo J, Payen D. Influence of arterial dissolved oxygen level on venous oxygen saturation: don't forget the $\mathrm{PaO}_{2}$ !. Shock. 2014;41(6):510-3. https://doi.org/10.1097/SHK.00000 00000000162 ISSN 15400514.
31. Rupert P, Deborah D, Jayne F, Andrew R, Michael GR, David $B E$. Changes in central venous saturation after major surgery, and association with outcome. Crit. Care. 2005;9(6):R694-9. https:// doi.org/10.1186/cc3888 ISSN 1466-609X.

32. Vallée F, Vallet B, Mathe O, Parraguette J, Mari A, Silva S, Samii K, Fourcade O, Genestal M. Central venous-to-arterial carbon dioxide difference: an additional target for goal-directed therapy in septic shock? Intensive Care Med. 2008;34(12):2218-25. https ://doi.org/10.1007/s00134-008-1199-0 ISSN 03424642.

33. Connors AF Jr, Speroff T, Dawson NV, Thomas C, Harrell FE Jr, Wagner D, Desbiens N, Goldman L, Wu AW, Califf RM, Fulkerson WJ Jr, Vidaillet H, Broste S, Bellamy P, Lynn J, Knaus WA. The effectiveness of right heart catheterization in the initial care of critically ill patients. Jama. 1996;276(11):889-97.

34. Ramsey SD, Saint S, Sullivan SD, Dey L, Kelley K, Bowdle A. Clinical and economic effects of pulmonary artery catheterization in nonemergent coronary artery bypass graft surgery. J. Cardiothorac. Vasc. Anesth. 2000;14(2):113-8. https://doi.org/10.1016/ S1053-0770(00)90001-6 ISSN 10530770.

35. Nashef SAM, Roques F, Sharples LD, Nilsson J, Smith C, Goldstone AR, Lockowandt U. Euroscore II. Eur. J. Cardio-thoracic Surg. 2012;41(4):734-45. https://doi.org/10.1093/ejcts/ezs043 ISSN 10107940. 